\title{
Sharing intellectual property rights-an exploratory study of joint patenting amongst companies
}

\author{
John Hagedoorn
}

Joint patenting by companies, the sharing of property rights on inventions, is a relatively unknown phenomenon that is generally seen by patent lawyers and firms alike as a second-best option that, if possible, should be avoided. However, the number of joint patents has increased during the last couple of decades and despite its impopularity firms frequently engage in co-ownership of patents. This exploratory study is one of the first contributions that provides insight into relevant, international, legal complications of joint patenting, sectoral trends and patterns and the motivation of companies to enter into these specific patenting agreements.

\section{Introduction}

A small number of papers by Duguet $(1994,1996)$ and Hagedoorn et al. (2003) investigate the possible relationship between the degree of $R \& D$ partnering of companies and their sharing of intellectual property rights through jointly owned patents. The basic idea behind these papers is rather straightforward. It is well known that in general there exists a positive relationship between the R\&D input of companies and their R\&D output through patents (Griliches, 1998). Mutatis mutandis, one should find a similar relationship between the participation of companies in inter-firm R\&D partnerships and the degree to which they share the results of this joint R\&D by means of jointly owned patents. The population analysed by Hagedoorn et al. (2003) consists of thousands of partnerships and thousands of joint patents of companies that were engaged in $R \& D$ partnering. Also, each of these forms of inter-firm interaction demonstrates a pattern of clear growth during recent decades. Nevertheless, the authors were unable to demonstrate any statistical relationship between both phenomena. They did, however, find that the experience of companies with joint patenting as such has a positive effect on future joint-patenting activities. As this joint patenting has increased substantially in recent decades (see also Hicks and Narin, 2001) and as there appears no clear-cut explanation for this growth, an exploratory study might be useful to shed some light on this, outside the inner circle of patent lawyers and patent researchers, little known phenomenon. 
To the best of my knowledge, this paper is the first contribution to present a detailed overview of some basic characteristics of joint patenting in a combination of:

- an analysis of some relevant legal aspects of joint patenting;

- a comparison with other forms of patent sharing and transfer of intellectual property rights;

- a description of some main trends in joint patenting; and

- a discussion of the motivation for co-owned patenting.

Throughout this paper I will refer to patent-owners as companies. It should be clear that in general patent-owner refers to any legal body, ranging from individuals to research institutes, universities and companies. However, unless specified otherwise, I will concentrate on companies as patent-holders, not only as merely a shorthand for all possible legal forms of patent-holders, but primarily because I assume that, more than universities and public research institutes, companies have a clear incentive to monopolise the property rights on their inventive activities. In that sense, the questions that I have regarding joint patenting are most conspicuously expressed in the case of joint patenting among companies.

In the following section I will first describe the phenomenon of joint patenting itself, picture some of its legal aspects including some international differences, and briefly compare joint patenting with cross-licensing, licensing for reciprocity, pooled patents, and patent infringement agreements. The next section discusses the data bases used to present the general trends in joint patenting and it also provides some information on the selection of data and the specifics of the jointly owned patents analysed in this paper. This is followed by an overview of some of the main trends in joint patenting in terms of historical developments and sectoral patterns. The next section examines the rationale for joint patenting both from an empirical and a theoretical perspective. Main findings and conclusions are discussed in the last section.

\section{Joint patents and other forms of shared intellectual property rights-some legal issues}

Patents are government grants of the exclusive right to make, use or sell an invention, usually for a limited period of time (16-20 years). This exclusive right implies that a patent is a class of property that can be traded as well as shared with others. Seen from the perspective of the overall trajectory of product and process development, patents are usually granted during the early phase of this trajectory, i.e. before commercial feasibility or the actual introduction of new products (Posner, 1986). The above also applies to joint patents, where two or more patent-holders (e.g. companies) are assigned to one patent. The main difference with regular patents is that in the case of joint patenting, two or more co-assignees are understood to have jointly filed a patent on an invention with a patent office (Lackey, 1957; Duguet, 1994; Terry, 1999; American Bar Association, 2001). To phrase the status of joint ownership of a patent in legal 
terminology, as found for instance in the US Patent Act: '. . when an invention is made by two ore more persons jointly, they shall apply for a patent jointly and each make the required oath ... Inventors may apply for a patent jointly even though (1) they did not physically work together or at the same time, (2) each did not make the same type or amount of contribution, or (3) each did not make a contribution to the subject matter of every claim of the application ...' (Title 35 USC $\$ 116$ ).

From an economic perspective the joint ownership of patents creates, depending on the number of proprietors, a form of duopoly or tight oligopoly that appears at first somewhat similar to a restrictive licensing agreement (Fershtman and Kamien, 1992; Aoki and $\mathrm{Hu}, 1999)$. However, it is important to notice that the actual property rights of joint patents are quite different from other multi-party patent agreements, such as cross-licenses, licenses for reciprocity, pooled patents, and patent infringement agreements. Cross-licensing usually occurs when patents of different companies 'block' each other because each patent infringes one or more patents of another company. In that case, a cross-licensing agreement, based on patent exchanges or 'swaps', gives the right to use these patents by parties that are subject to the exchange agreement. In such an agreement the value of individual licenses or packages of licenses is calculated by both parties and subject to the agreement (Telesio, 1979; Grindley and Teece, 1997). With licensing for reciprocity, companies exchange licenses to supplement their own research or other inventive activities with licensed technology in order to avoid patent protection on a particular subject of their inventive activity (Hagedoorn, 1990). Pooled patents refer to the situation where companies decide to combine patents ex post to improve inventions or to set up a de facto standard by means of patents of multiple patent-owners. Finally, a patent infringement agreement is an ex ante agreement where patent-holders establish a binding contract through which particular patent infringements will go unpunished. This comes close to an ex ante version of a cross-licensing agreement (Marjit et al., 2001).

In most of these different forms of patent agreements, particularly in cross-licenses, licensing for reciprocity and pooled patents, companies decide to 'share' the property rights of existing patents. This legal procedure is chosen to avoid infringing the patent rights on inventions that were made by at least one of the companies. As such these forms of patent sharing are not directly related to a situation where companies jointly file a new patent, after which joint ownership is established.

One important aspect of joint patenting, that might have far reaching consequences for companies that possess joint patents, is the actual sharing of the property rights between the patent-holders. For instance, under US patent law each co-owner of a patent is free to utilize his/her interest in practically any way, without the consent or without accounting to any of the other owners. This implies that in the USA each co-owner of a joint patent can use or license the patent without consulting or sharing the proceeds with the other co-owners (see Title 35 USC $\$ 262$; Lackey, 1957; Terry, 1999; O’Reilley, 2000; American Bar Association, 2001). This rule is applied in absence of an agreement between co-owners that would specify otherwise. However, the legal 
ramifications of such alternative agreements that regulate the specifics of joint ownership are rather complex and some of these agreements have failed in US courts (Lackey, 1957; Lowenstein, 1998; Terry, 1999).

Interestingly, the wording of the property rights related to joint patenting is quite similar in the UK 1977 Patents Act. However, under UK law the actual interpretation of this part of the Patents Act indicates that the 'no need to obtain consent' clause only applies if a co-owner of a patent wants to exploit the patent himself/herself. In all other cases, each joint-proprietor cannot effectively exploit a joint patent through licensing or assign a share in a patent independently without the consent of the other owner(s) (Marchese, 1999; Brown, 2000). A similar interpretation of the property rights of joint patenting is found in Canada and Japan (Nakano, 2000a,b; Woodley, 2000; Langford, 2001).

For European countries, more specifically the European Union, the situation is even more complex as the European Patent Convention merely regulates the patent application process, whereas patent litigation is still the responsibility of national courts. This fragmentation of the European 'market' for patents and the actual patent protection under different national laws creates a diverse picture regarding the legal implications for European patents. It certainly leads to substantial variation in the treatment of specific elements of patent law in Europe, such as the legal consequences of co-ownership in joint patenting (Gutterman, 1997). Therefore, the legal and ownership implications of joint patenting under European law differ from country-to-country and can only be determined on a country-by-country basis. This particular situation with regard to European patents can, however, also stimulate co-owned patenting as companies from different European Union member-states can jointly file patents, whereas the actual patent protection is found in the home-country of each co-owner (Duguet, 1994).

These different legal interpretations of shared property rights for patents partly reflect the difficulties related to the incompleteness of the patent system as found in the imperfect nature of knowledge codification and the fact that the use of right to an idea is not always totally clear (Bessy and Brousseau, 1998; Kesan and Banik, 2000). The US legal system with regard to co-owned patents is probably the most radical solution to avoid the moral hazard that comes with unclear ownership. Each co-owner of a patent has identical, bilateral or multilateral property rights and the legal protection against patent infringements is similar to 'normal' patents. ${ }^{1}$ The difficulty with additional contractual agreements, that redefine the specifics of joint ownership within a US joint patent, stems from the fact that these agreements are relational, incomplete contracts (Milgrom and Roberts, 1992) that attempt to regulate the exclusiveness of knowledge and technology for particular partners within an otherwise joint ownership contract

\footnotetext{
${ }^{1}$ However, this shared nature of ownership implies that in the USA patent infringement suits can only be brought if all owners are named in the lawsuit (Lowenstein, 1998; O’Reilley, 2000). This is different from many other countries where co-owners can individually file patent suits (Brown, 2000; Lowenstein, 1998; Nokano, 2000a,b; Woodley, 2000).
} 
(Lowenstein, 1998). The legal problems that result from these specific additional agreements are expected to be similar to the somewhat unclear nature of the European legal system where subcontracting arrangements and differences in national patent rulings can obfuscate the actual property rights associated with co-owned patents.

Given the legal complexity that surrounds joint-patenting, both in terms of international differences and the actual interpretation of contractual arrangements, it is no surprise that many legal experts regard the joint ownership of intellectual property rights, such as patents, as fraught with problems, and therefore as a last resort if other arrangements have failed (Lowenstein, 1998; Marchese, 1999; Terry, 1999). On the other hand, as discussed below, joint patenting has become more popular amongst companies as the number of joint patents has increased during the previous decades.

\section{Data on joint patenting and search methodology}

In order to get a better understanding of some basic trends and patterns in joint patenting, I will use data on US patents from the US Patent and Trademark Office (USPTO). Although this US data could imply a bias in favour of US companies and against non-US firms, the patent literature indicates that most innovative, non-US companies that play some role in their product markets are known to also patent extensively in the USA. Indeed, the Appendix demonstrates that non-US companies are well represented in the group of leading joint patenting companies in the USA. Other reasons to choose US patents are the importance of the US market, the genuine patent protection offered by US authorities, and the level of technological sophistication of the US market which makes it almost compulsory for non-US companies to file patents in the USA. See Cantwell and Hodson (1991) and Patel and Pavitt (1991) for a further discussion of these arguments in favour of using of US patent data. Also, analysing co-owned US patents is preferred to analysing European patents because, unlike the European system, the US patent system is characterized by a single regime of patent application, patent protection and patent litigation.

The actual data set on US jointly owned patents was acquired from CHI Research Inc., which helped me separate jointly owned patents from 'regular' patents. The data refers to the period 1989-1998. This period was chosen because it follows a phase of gradual growth in the number of co-assigned patents leading to a relatively large number of joint patents during the 1990s (see also Hicks and Narin, 2001). The selected patents fit the following criteria:

- they are so-called Type 1 (utility) patents granted in the years 1989-1998;

- patents are co-assigned to at least two companies that do not share a common parent company (organizations other than companies are excluded).

The general population of jointly owned patents that forms the starting point for this research comprises a total of 9585 patents, with 20569 assignees and 13052 pairs of assignees or pairs of companies. From this data set I selected the joint patents owned by 
companies from North America (USA and Canada) and Europe (the European Union and the European Free Trade Association). Companies to which these co-owned patents were granted were identified by means of computer-based search for the legal status of applicants, in combination with CHI's Tech-Line database and manual inspection. I excluded joint patents of companies from within Asian countries because in many countries, Japan and Korea in particular, it is difficult to detect whether two 'firms' mentioned as co-assignees of patents are actually a part of the same complex 'company' such as a keiretsu or a chaebol. For North American and European companies, I could check through Disclosure whether co-assignees in these patents are indeed two separate companies. International joint patenting by North American and European companies with Asian companies is included in the data set. The unclear status of jointly owned patents involving companies from Asia only applies to intra-Asian joint patenting, and not, for instance, to a US and a Japanese company, where it is less difficult to detect whether the patent agreement is between two separate companies.

The identification of the actual legal and company status of applicants, the consolidation of subsidiaries, the separation of companies from various research institutes and other applicants, and the identification of home countries of parent companies took a considerable effort. Computer-based search for indicators of companies such as 'co.', 'inc.', 'ltd', etc. combined with CHI's Tech-Line database and manual inspection was necessary to identify unique companies and their country of origin in order to arrive at this sample of patents co-owned by at least two companies.

After these selection criteria were applied to the initial set of 9585 patents, the dataset analysed in this paper was reduced to 3460 joint patents granted during the period 1989-1998.

These data on co-assigned patents are available at the level of individual companies, patent classes (and many corresponding SIC-related product groups as found in CHI's Tech-Line database) and the home countries of patent-owners. Additional detailed information on the database and the selection of co-owned patents is available from the author.

In addition to the analysis of the data on US co-owned patents, I also conducted field research through a series of in-depth interviews with corporate patent lawyers and patent specialists, representing twelve leading European companies that are among the list of top co-owners of patents in the USA (see Appendix). These interviews centred around questions that dealt with the rationale for joint patents, the role of inter-firm $R \& D$ collaboration and the contractual embedding of co-owned patents. The interviews were guided by a list of open-ended questions. Cases from the USPTO data set were used to clarify specific reasons for obtaining a co-owned patent. Although the interviews mainly focussed on the general strategy of companies with regard to this subject, most companies asked me to remain anonymous and not to reveal some of the specific and confidential company information regarding the contractual specification of the property rights of particular jointly owned patents. 


\section{Some general trends and patterns in joint patenting}

It is important to note that joint patenting is not a new phenomenon. Already during the nineteenth century and the first half of the twentieth century there was quite a substantial number of jointly owned patents in the USA (Lackey, 1957). There are some clear indications that the number and the share of joint patents have increased further during the second half of the twentieth century. For instance, according to one of the few non-legal sources on this topic (i.e. Hicks and Narin, 2001), the share of all US domestic, jointly owned patents in all US patents has risen from $0.2 \%$ in the early 1980 s to about $1.5 \%$ at the turn of the century. It appears, however, that there is quite some variation in these percentages with regard to technologies or sectors of industry. In 1999 the share of US domestic, jointly owned patents in chemicals was still less than $1.0 \%$, while in biotechnology about $7 \%$ of the domestic US patents were jointly owned. According to Hicks and Narin (2001), there is a disproportionate share of US patentees splitting their property rights through domestic, jointly owned patents in fields such as biotechnology and pharmaceuticals, telecom, semiconductors, measuring and medical equipment, office equipment, computers, electrical appliances, aerospace, industrial process equipment and other capital goods.

Studying European co-owned patents by French companies, Duguet $(1994,1996)$ found that during the period 1980-1989 about 15\% of the European patents of French companies was jointly owned with other companies. This percentage appears to overestimate the actual share of joint patenting by different patent-owners as jointly owned patents by two or more (international) subsidiaries of French companies and jointly owned patents by a headquarter of a French company and one of its (international) subsidiaries are counted as joint patents. However, Duguet's study does demonstrate that during the 1980s joint patenting was already quite well established in the European patent system. His study also shows that a relatively large share of these joint patents were filed in high-tech sectors that are comparable to those found for the US situation by Hicks and Narin (2001).

The studies mentioned in the above looked at different populations of standard patents and jointly owned patents, i.e. European patents or domestic US patents including other patentees than companies. In order to get a better understanding of the relative importance of jointly owned company patents as a proportion of standard company patenting, one has to make a comparison with a similar group of industryrelated patent classes for companies from the same group of countries. Based on the data available, I estimate that during the period 1989-1998 a constant annual share of around $1.3 \%$ of all of these US patents are jointly owned by two or more companies. This percentage comes close to the share mentioned in Hicks and Narin (2001).

The actual growth pattern in the sample of US joint patents analysed in this paper is presented in Figure 1. There is a clear increase in the number of co-owned patents, in particular during the second half of the 1990s, following a similar growth pattern in standard patents. In this data set on joint patenting there is an annual number of between two hundred and three hundred joint patents granted during the years 


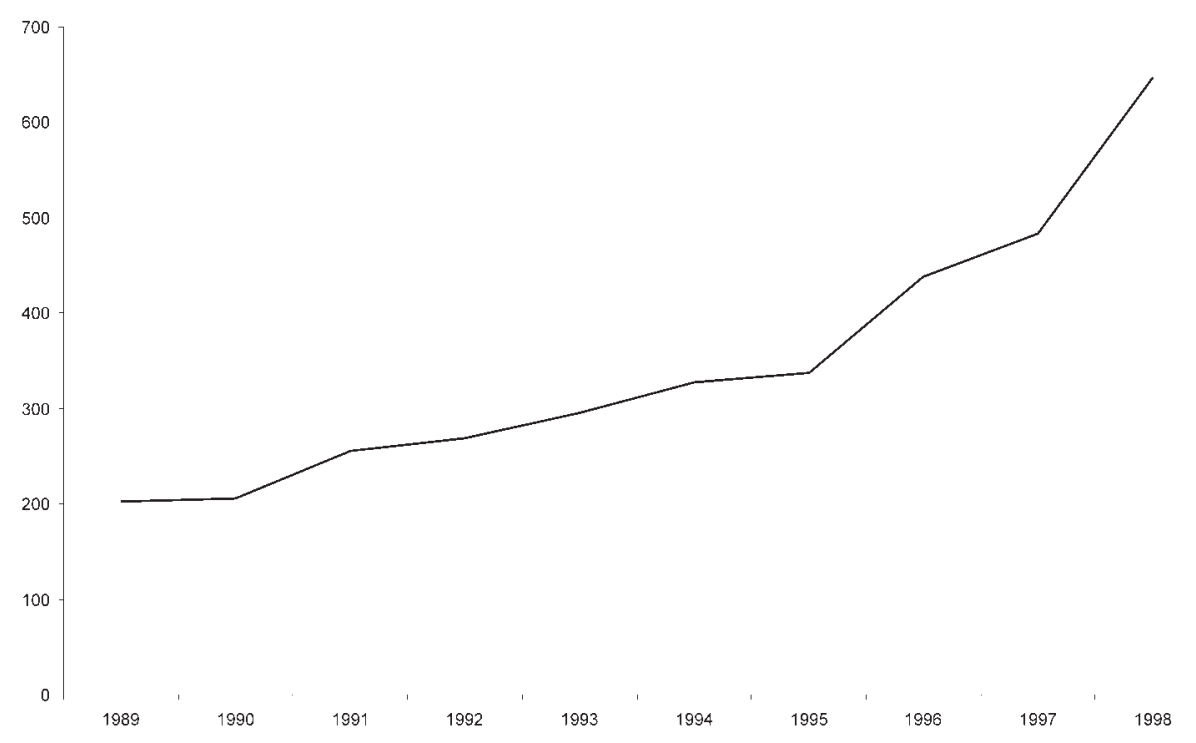

Figure 1 Growth in the sample of co-owned patents in the USA, 1989-1998.

Source: see Table 1.

1989-1993. During the second half of the 1990s the number of co-owned patents apparently doubled to nearly 650 patents owned by two or more companies. In other words, these data indicate that at the end of the previous century the number of jointly owned patents tripled within a period of only ten years. However, due to the parallel growth in all patenting activities, the share of joint patenting in the overall patenting activity has remained fairly constant throughout this period.

In terms of the industry breakdown of these joint patents (see Table 1), the chemical industry $(32.1 \%)$ and the information technology industries (26.7\%) are sectors where the largest numbers of co-owned patents are found, followed by instrumentation (14.9\%), pharmaceuticals, including pharma-biotechnology (11.5\%), the automotive industry (5.5\%) and aerospace and defence $(3.7 \%) .^{2}$ Other sectors, such as food and beverages, steel and metals and oil and gas, seem to play hardly any role at all. These findings are somewhat similar to those of Hicks and Narin (2001) and Duguet (1994, 1996). Also, this sectoral distribution appears to be to be quite stable over the ten year period, as there are relatively small changes in the yearly distributions within these sectors and no real shifts in the distribution across sectors.

If one compares the sectoral distribution of joint patenting with the distribution of

\footnotetext{
${ }^{2}$ It is well-known that patent classifications only partly coincide with standard industry classes that can be applied to identify sectors of industry. In consultation with CHI, I related patents in this sample to the industries that are mentioned in this study, using CHI's Tech-Line database for the correspondence of patent classes with SIC classes.
} 
Table 1 Sectoral distribution (\%) in the sample of co-owned patents in the USA (1989-1998)

\begin{tabular}{|c|c|c|c|c|c|c|c|c|c|c|c|}
\hline & 1989 & 1990 & 1991 & 1992 & 1993 & 1994 & 1995 & 1996 & 1997 & 1998 & Total \\
\hline Aerospace and defence & 4.1 & 3.7 & 5.1 & 5.3 & 2.0 & 3.6 & 4.7 & 4.0 & 3.7 & 2.4 & 3.7 \\
\hline Automotive & 7.7 & 5.9 & 6.4 & 6.9 & 4.4 & 4.4 & 4.7 & 4.6 & 5.9 & 5.6 & 5.5 \\
\hline Chemicals & 33.3 & 35.6 & 35.8 & 31.7 & 35.7 & 35.8 & 30.0 & 28.9 & 31.0 & 29.9 & 32.1 \\
\hline Pharmaceuticals & 5.4 & 4.6 & 9.1 & 13.5 & 14.0 & 8.6 & 11.1 & 10.3 & 16.7 & 13.2 & 11.5 \\
\hline Food and beverages & 2.3 & 1.8 & 0.7 & 0.3 & 0.6 & 2.2 & 0.3 & 0.8 & 0.4 & 1.5 & 1.0 \\
\hline Instruments & 16.7 & 19.6 & 10.8 & 16.0 & 19.3 & 18.9 & 13.7 & 12.7 & 11.5 & 14.7 & 14.9 \\
\hline Information technology & 21.6 & 22.4 & 26.0 & 22.6 & 19.6 & 21.7 & 32.0 & 34.1 & 28.0 & 28.7 & 26.7 \\
\hline Metals & 3.2 & 4.6 & 4.1 & 2.5 & 3.5 & 3.3 & 2.8 & 2.8 & 1.7 & 2.7 & 2.9 \\
\hline Oil and gas & 5.9 & 1.8 & 2.0 & 1.3 & 0.9 & 1.4 & 0.8 & 1.6 & 1.1 & 1.2 & 1.6 \\
\hline
\end{tabular}

Source: own calculations based on data from US Patent Office and CHI Research Inc.

Table 2 Distribution (\%) of US patents (standard patents and co-owned patents), 1989—1998

Industries

All patents (excl. joint patents)

Co-owned patents

$\begin{array}{lrr}\text { Aerospace and defence } & 4.2 & 3.7 \\ \text { Automotive } & 5.8 & 5.5 \\ \text { Chemicals } & 27.1 & 32.1 \\ \text { Pharmaceuticals } & 7.2 & 11.5 \\ \text { Food and beverages } & 0.9 & 1.0 \\ \text { Instrumentation } & 20.8 & 14.9 \\ \text { Information technology } & 31.1 & 26.7 \\ \text { Steel and metals } & 1.8 & 2.9 \\ \text { Oil and gas } & 1.1 & 1.6 \\ \text { Total } & 100.0 & 100.0\end{array}$

Source: see Table 1.

standard patents (see Table 2), one finds a number of interesting differences. ${ }^{3}$ Chemicals and pharmaceuticals (including pharmaceutical biotechnology) are found to have a disproportionate share of joint patenting activities. Although information technology and instrumentation account for a large number of co-owned patents, their

\footnotetext{
${ }^{3}$ The differences between the distribution for joint patenting and the distribution for regular patents have to be interpreted somewhat cautiously because the data for joint patenting refer only to companies, whereas the data for regular patents include all patentees. Given the large number of US patents it is practically impossible to select only patents granted to companies.
} 
share in joint patenting is substantially lower than their share in standard patenting. The share of other sectors in joint patenting is somewhat similar to their share in standard patenting and/or their role in joint patenting stays at a rather low level.

\section{The rationale for joint patenting}

Theoretically it is rather difficult to understand why, given the legal status of joint patents, companies would share their patents with other companies and there appears to be no literature that explains the likely economic or managerial rationale behind this phenomenon. However, the literature on ex ante licensing and cross-licensing makes a number of interesting suggestions regarding the role of strong or weak property rights that affect the behaviour of companies and that might have some relevance for understanding joint patenting. Anand and Khanna (2000) and Grindley and Teece (1997) suggest that ex ante licensing, through which knowledge is shared before it is fully developed, is more common in industries where intellectual property rights are strong because the inventions of companies are well protected through patents. Ex ante licensing appears less important in industries where property rights are weak as companies can easily circumvent and re-engineer the inventions of others. For cross-licensing, the ex post sharing of patents, Anand and Khanna (2000) suggest the opposite, i.e. companies are expected to have a higher preference to share their inventions through cross-licenses in industries where patent protection is weak because this enables them to reap the benefits of inventions before they are subject to imitation. They expect a lower proportion of cross-licenses in industries with a strong intellectual property regime because of efficient patent protection. Joint patenting comes closest to a combination of ex ante licensing and cross-licensing. However, it is difficult to bridge the contradiction that follows if one would combine the suggested relationship between the strength of intellectual property rights and these different contracting mechanisms.

Further insight into the empirical situation might generate some understanding of the role of the strength or weakness of intellectual property rights in different industries vis-à-vis joint patenting. My data (see Tables 1 and 2) suggest that the strength or weakness of intellectual property rights protection, also known as the strength or weakness of a regime of appropriability, could affect the degree to which certain industries have a higher or lower propensity to establish co-owned patents. ${ }^{4}$ Joint patenting plays little or no role in sectors with rather weak intellectual property rights protection such as food

\footnotetext{
${ }^{4}$ Based on the well-established body of literature regarding the strength and weakness of intellectual property rights protection and regimes of appropriability (see Mansfield, 1986; Levin et al., 1987; Winter, 1987; Anand and Khanna, 2000), I reconstructed a list of sectors indicating different levels of strength for intellectual property rights protection and regimes of appropriability. List of sectors, their regime of appropriability or strength of intellectual property rights: pharmaceuticals (strong); information technology (moderate); aerospace and defence (moderate); instrumentation (moderate); automotive (weak-moderate); chemicals (strong); food and beverages (weak); metals (weakmoderate); oil and gas (weak-moderate). Source: Levin et al. (1987) and Winter (1987).
} 
and beverages, metals, oil and gas. Sectors with moderate regimes of appropriability such as aerospace and defense and automotive also do not appear to be major fields of joint patenting. Information technology and instrumentation, sectors with large numbers of patents, where intellectual property rights protection is of moderate importance, take an important share of the total number of co-owned patents but this share is lower than expected on the basis of their strong overall patenting position. Co-owned patents are, however, disproportionately important in industries with strong regimes of appropriability such as chemicals and pharmaceuticals.

In addition to these descriptive statistics, my field research on the joint patenting behaviour of companies provides some additional information. The picture that emerges from the interviews with companies that are heavily involved in joint patenting reveals that co-owned patents are largely the result of small-scale inter-firm R\&D collaboration where companies are unable to divide the inventions among the partners. It was stated by all companies that I interviewed that informal R\&D partnerships and small joint research projects are a major cause of joint patenting. In some cases patent rights were transferred during the acquisition process of a company as the acquired company was about to file a number of patent applications and the acquiring company was listed as the co-owner of the patent. In some other cases, there was informal R\&D collaboration with a number of spin-off companies which eventually led to the joint ownership of patents. Given the growth of (informal) R\&D collaboration in high-tech industries it was expected by companies that joint patenting will continue to grow, particularly as it is frequently unfeasible to divide the property rights of inventions from small projects through different packages of patents.

However, all patent specialists did express that their companies still see joint patents as a second best option, not only in the USA but also in other countries. If possible, companies prefer to have standard patents as a result from $\mathrm{R} \& \mathrm{D}$ collaboration. Nevertheless, over the years these companies have learned how to deal with joint patenting and their reluctance to co-own patents has gradually decreased somewhat. It was mentioned by all companies that, given the legal ramifications of additional contracts, 'watertight' supplementary contracts are extremely important in order to have joint patents embedded in agreements that specify specific property rights as part of a standard joint patenting contract. The increased experience that companies have with forging these additional contracts was stated as a major explanation for the growth in the absolute number of jointly owned patents.

\section{Discussion and conclusions}

Although in recent decades the number of jointly owned patents has increased significantly, first in both relative and absolute terms and later running parallel with the increase in total patenting activities, co-owned patents are generally seen as suboptimal. If companies would have a choice, it seems they would prefer to have only regular 
patents. In their attempt to regulate the property rights that come with joint patenting companies embed their co-owned patents in specific, complex contractual arrangements that specify the actual distribution of responsibilities and the concrete terms of third-party licensing, payments, litigation, etc. However, no matter how many details are covered by specific arrangements, these contracts specifying the property rights in co-owned patents will remain incomplete, relational contracts. The differences in international patent laws with regard to the legal status of joint patenting only adds to the incomplete nature of such contracts.

Extensive experience of companies with the application for joint patents and experience in writing these additional contracts are important for companies to successfully enter into a number of co-owned patenting agreements. This is probably also one of the main reasons why Hagedoorn et al. (2003) found the actual experience of companies with co-owned patenting to be the main determinant of the probability of the future joint patenting activity of companies.

Apart from this experience with the legal complexities of joint patenting, the sheer fact that many companies are apparently engaged in a wide variety of relatively small, unobserved joint R\&D projects will affect the occurrence of joint patenting. It is well known that the number of $\mathrm{R} \& \mathrm{D}$ partnerships has increased dramatically during the past decades and that this increase is largely due to relatively small, joint R\&D projects in high-tech sectors (Hagedoorn, 2002). Apart from these formal, publicly announced agreements, many companies are also engaged in 'hidden' small joint R\&D projects for which it is apparently impossible to divide the property rights. If these small joint projects are successful and if patenting is a relevant option, this will lead to only one or two joint patents per project. In other words, the indivisibility of single inventions from small scale and informal R\&D partnering is another major explanation for the growth in joint patenting.

The industry-specific context of joint patenting appears related to a number of factors. It is well established that a disproportionate share of all patenting takes place in high-tech, i.e. R\&D-intensive, industries (Griliches, 1998), sectors that are, as mentioned before, also R\&D partnering-intensive industries. Also, the strength of the regime of appropriability or the strength of property rights in industries affects the degree to which companies can effectively use patents, including the patents that they jointly hold with others. Or to put it differently, given the complexity and uncertainty surrounding joint patenting, it is rational for companies to obtain co-owned patents in a situation where they will find effective patent protection in a moderate to strong regime of appropriablility. At the aggregated level of industries, it is this combined effect of patent intensity, (informal) partnering intensity and the strength of intellectual property rights that appears to explain why there is such an abundance of joint patenting in pharmaceuticals, chemicals, instruments, and information technology sectors.

In addition to the regime of appropriability, inter-industry differences with regard to the separability of knowledge into a set of independent pieces of a patentable 
invention might also play a role. ${ }^{5}$ This factor could explain why the intensity of joint patenting is smaller in information technology and instrumentation than in chemicals and pharmaceuticals. Indeed, information technology and instrumentation are modular technologies, due to standardized interfaces. It is therefore easy to split any system into a set of independent components that can be separately patented. Firms involved in common $\mathrm{R} \& \mathrm{D}$ projects can therefore easily separate the result of their joint effort. This is quite different in chemicals and pharmaceuticals since there are many interdependencies between the various components of a process leading to a product. It is therefore more difficult to claim for different patents, both for the products and for the process, and for the different steps of a single process.

\section{Acknowledgements}

I would like to thank Geert Duysters, Diana Hicks and two anonymous referees for their comments on an earlier draft of this paper, and Marc van Ekert for his assistance in organizing the data.

\section{Address for correspondence}

MERIT, Faculty of Economics and Business Administration, University of Maastricht, PO Box 616, 6200 MD Maastricht, The Netherlands. Email: j.hagedoorn@os.unimass.nl.

\section{References}

American Bar Association (2001), Section on Intellectual Property Law, Committee No. 106, General Information Concerning Patents. American Bar Association: Washington, DC.

Anand, B. N. and T. Khanna (2000), 'The structure of licensing contracts,' Journal of Industrial Economics, 43, 103-135.

Aoki, R. and J.-L. Hu (1999),' Licensing vs. litigation: the effect of the legal system on incentives to innovate,' Journal of Economics and Managerial Strategy, 8, 133-160.

Bessy, C. and E. Brousseau (1998), 'Technology licensing contracts: features and diversity,' International Review of Law and Economics, 18, 451-489.

Brown, J. (2000), 'Allocations of ownership of inventions in joint development agreements- the United Kingdom perspective,' Les Nouvelles, 35, 173-175.

Cantwell, J. and C. Hodson (1991), 'Global R\&D and UK competitiveness,' in M. Casson (ed.), Global Research Strategy and International Competitiveness. Blackwell: Oxford, pp. 133-182.

Duguet, E. (1994), 'La coopération technique au travers des co-brevets européens,' Economie et Statistique, 275-276, 135-148.

${ }^{5}$ I would like to thank one of the referees of this journal for drawing my attention to this aspect of joint patenting. 
Fershtman, C. and M. I. Kamien (1992), 'Cross-licensing of complementary technologies,' International Journal of Organization, 10, 329-348.

Griliches, Z. (1998), RઐD and Productivity—The Economic Evidence. The University of Chicago Press: Chicago, IL.

Grindley, P. C. and D. J. Teece (1997), 'Managing intellectual capital: licensing and cross-licensing in semiconductors and electronics,' California Management Review, 39, 8-41.

Gutterman, A. S. (1997), Innovation and Competition Policy-a Comparative Study of the Regulation of Patent Licensing and Collaborative R\&D in the US and the European Community. Kluwer: London.

Hagedoorn, J. (1990), 'Organisational modes of inter-firm cooperation and technology transfer,' Technovation, 10, 17-31.

Hagedoorn, J. (2002), 'Inter-firm R\&D partnerships—an overview of major trends and patterns since 1960,' Research Policy, 31, 477-492.

Hagedoorn, J., H. van Kranenburg and R. Osborn (2003), 'Joint patenting amongst companies-exploring the effects of inter-firm R\&D partnering and experience,' Managerial and Decision Economics, 24, 71-84.

Hicks, D. and F. Narin (2001), 'Strategic research alliances and 360 degree bibliometric indicators,' in J. E. Jankowski, A. N. Link and N. S. Vonortas (eds), Strategic Research Partnerships-Proceedings from a National Science Foundation Workshop. National Science Foundation: Washington, DC, pp. 133-145.

Kesan, J. P. and M. Banik (2000), 'Patents as incomplete contracts: aligning incentives for R\&D investment with incentives to disclose prior art,' Washington University Journal of Law and Policy, 2, 23-54.

Lackey, H. A. (1957), 'Problems in joint ownership of patents,' Vanderbilt Law Review, 11, 697-735.

Langford, V. (2001), 'Allocating ownership of inventions and patents in joint development agreements,' Intellectual Property and Technology, 8, 1-3.

Levin, R., A. Klevorick, R. Nelson and S. Winter (1987), 'Appropriating the returns from industrial research and development,' Brookings Papers on Economic Activity, 3, 783-820.

Lowenstein, D. A. (1998), 'Dangers in joint patent ownership,' Les Nouvelles, 33, 3-6.

Mansfield, E. (1986), 'Patents and innovations: an empirical study,' Management Science, 32, $173-181$.

Marchese, D. (1999), 'Joint ownership of intellectual property,' European Intellectual Property Review, 21, 363-369.

Marjit, S., A. Mukherjee and H. L. Shi (2001), 'Cooperation in R\&D: the case of patent infringement agreements,' Journal of Economic Behaviour and Organization, 45, 383-401.

Milgrom, P. and J. Roberts (1992), Economics, Organization and Management. Prentice-Hall: Englewood Cliffs, NJ.

Nakano, K. (2000a), 'Patent rights of co-owners in Japan,' Les Nouvelles, 35, 48-53.

Nakano, K. (2000b), 'Allocations of ownership of inventions in joint development agreements-the Japanese perspective,' Les Nouvelles, 35, 181-182. 
Patel P. and K. Pavitt (1991), 'Large firms in the production of the world's technology: an important case of non-globalization,' Journal of International Business Studies, 22, 1-21.

Posner, R. (1986), Economic Analysis of Law. Little, Brown \& Company: Boston, MA.

O'Reilley, D.P. (2000), 'Allocations of ownership of inventions in joint development agreements—-the United States perspective,' Les Nouvelles, 35, 168-172.

Telesio, P. (1979), Technology Licensing and Multinational Enterprises. Praeger: New York.

Terry, K. R. (1999), 'Implications of joint ownership of patents in the USA,' Industry and Higher Education, 13, 198-202.

Winter, S. G. (1987), 'Knowledge and competence as strategic assets,' in D. J. Teece (ed.), The Competitive Challenge-Strategies for Industrial Innovation and Renewal. Ballinger: Cambridge, MA, pp. 159-184.

Woodley, J. H. (2000), 'Allocations of ownership of inventions in joint development agreements— the Canadian perspective,' Les Nouvelles, 35, 183-188.

Appendix The top fifty US and European firms with co-owned US patents (1989-1998)

\begin{tabular}{|c|c|c|}
\hline Company name & Country & $\begin{array}{l}\text { Number of } \\
\text { jointly owned } \\
\text { patents }\end{array}$ \\
\hline IBM & USA & 136 \\
\hline Siemens & Germany & 116 \\
\hline NCR & USA & 85 \\
\hline Imperial Chemical Industries & UK & 80 \\
\hline DuPont de Nemours \& Co & USA & 71 \\
\hline Daimler Chrysler & Germany & 69 \\
\hline Automobiles Citroen & France & 62 \\
\hline Automobiles Peugeot & France & 62 \\
\hline General Motors Corporation & USA & 60 \\
\hline Texas Instruments Incorporated & USA & 59 \\
\hline STMicroelectronics & France & 58 \\
\hline Hoechst & Germany & 55 \\
\hline Motorola & USA & 55 \\
\hline Novartis & Switzerland & 49 \\
\hline Delphi Automotive Systems & USA & 47 \\
\hline Philips Electronics & The Netherlands & 46 \\
\hline Elf Aquitaine & France & 46 \\
\hline Roche Holding & Switzerland & 41 \\
\hline C.R.M. Mezzo & Italy & 40 \\
\hline Symetrix & USA & 38 \\
\hline Degussa-Huls & Germany & 33 \\
\hline
\end{tabular}


Appendix Continued

\begin{tabular}{|c|c|c|}
\hline Company name & Country & $\begin{array}{l}\text { Number of } \\
\text { jointly owned } \\
\text { patents }\end{array}$ \\
\hline Dow Chemical & USA & 33 \\
\hline Ford Motor Company & USA & 33 \\
\hline Bayer & Germany & 31 \\
\hline France Telecom. & France & 30 \\
\hline Xerox Corporation & USA & 30 \\
\hline Minnesota Mining \& Mfg & USA & 29 \\
\hline Lucent Technologies & USA & 28 \\
\hline Rohm and Haas & USA & 26 \\
\hline ENI & Italy & 25 \\
\hline Intel & USA & 25 \\
\hline Raytheon & USA & 25 \\
\hline General Electric & USA & 24 \\
\hline Hewlett-Packard & USA & 24 \\
\hline Thyssen & Germany & 23 \\
\hline Exxon & USA & 22 \\
\hline Johnson \& Johnson & USA & 22 \\
\hline Sun Microsystems & USA & 22 \\
\hline DSM & The Netherlands & 21 \\
\hline General Hospital Corp. & USA & 21 \\
\hline Metallgesellschaft & Germany & 21 \\
\hline Baxter International & USA & 20 \\
\hline Kernforschungsanlage Julich & Germany & 20 \\
\hline Usinor Sacilor & France & 20 \\
\hline Akzo Nobel & The Netherlands & 19 \\
\hline Compaq Computer & USA & 19 \\
\hline Dow Corning & USA & 19 \\
\hline Fiat & Italy & 19 \\
\hline American Home Products & USA & 18 \\
\hline Bayerische Motoren Werke & Germany & 18 \\
\hline
\end{tabular}

